\title{
TECHNICAL EFFICIENCY OF SORGHUM PRODUCTION IN HONG LOCAL GOVERNMENT AREA OF ADAMAWA STATE, NIGERIA
}

\author{
Abba Mohammed Wakili, Researcher \\ Federal College of Education, P.M.B. 2042, Yola, Adamawa State, Nigeria \\ E-mail: boyaabba@yahoo.com
}

Received June 18, 2012

\begin{abstract}
This paper investigates the technical efficiency of sorghum production and its determinants, using the stochastic frontier production function which incorporates a model of inefficiency effects. Farm level data were collected from a sample of 100 sorghum farmers in Hong local government area of Adamawa state using structured questionnaires. The empirical result shows that land, seed, and fertilizer were the major factors that influence changes in sorghum output. Farm specific variables such as education, extension contact and household size were found to have significant effects on the technical inefficiency among the sorghum producers. The technical efficiency of farmers varied from 0.1562 to 0.9214 with a mean technical efficiency of 0.7262. The implication of the study is that efficiency in sorghum production among the farmers could be increased by $28 \%$ through better use of land, seed and fertilizer in the short term given the prevailing state of technology. This could be achieved through policy interventions by the government in terms of better access to land, improved seed and fertilizer. The inefficiency effect also shows that improved farmer's educational levels through better education and literacy campaigns would help tremendously to increase efficiency.
\end{abstract}

\section{KEY WORDS}

Production functions; Efficiency; Sorghum; Local government; Agricultural economics; Nigeria; Family labour; Hired labour; Production; Econometrics.

Agriculture plays a significant role in the economy Nigerian. The sector provides food for the timing growing population, employs about $70 \%$ of the labour force, and provide raw materials for our young industries (Adegboye, 2004). In view of the above, since independence the federal government of Nigeria has focused its attention of its agricultural policies on the small-scale farmers who constitute majority of the farming population. The rate of growth of Nigeria food production has been very slow; food production grows at the rate of $2.5 \%$ per annum in recent years while food demand has been growing at the rate of more than $3.5 \%$ per annum due to the rate of high rate of population growth of $2.8 \%(\mathrm{Na}-$ tional Bureau of Statistic, 2010).

The importance of sorghum in Nigeria cannot be over emphasized, because it provides food for both man and animals. Food and agricultural organization (F.A.O., 2003) reported that world annual sorghum production is over 60 million tones, of which Africa produces about 20 million tones. This makes sorghum the second most im- portant cereal grain in Africa after maize. According to Akinyele, (2006) he said that the production of the commodity is not given due consideration despite its importance in Nigeria. This can be seen in the decline in output of the commodity in the savannah zone, where sorghum is grown on an estimated area of 4.5 million ha with an annual production output of about 6 million tons (NAERLS,2007).This is a threat especially to those who widely cultivate the crop and consume it. The commodity is used in making alcohol and non alcohol drinks in Nigeria, particularly in the northern part of the country, it is also used for feeding of livestock and the stalks is used for making houses and making fences. Therefore to increase sorghum productivity, there is a need to understand the efficiency of production, since increase productivity is directly related to production efficiency, it is necessary to raise productivity of the farmers by helping them to reduce their technical inefficiencies.

Efficiency is concerned with the relative performance of the processes used in transferring 
given inputs into outputs. Farrell (1957) indentified three types of efficiency- technical, allocative and economic. Technical efficiency is defined as the ability of the firm to produce at maximum given little inputs with available technology. Efficiency measurement is that firms operate on the outer bound of production function, that is, on their efficiency frontier. When firms fail to operate on the outer bound of the production function, they are said to be technically inefficient. The stochastic frontier production function was first independently proposed by Aigner et al (1977) and Meeusen and Van den Broeck (1977). A stochastic frontier production function comprises a production function of the usual regression type with a compose disturbance term equal to the sum of two error components. One error component represents the effects of statistical noise (example weather, measurement error, etc) the other is attributed to technical inefficiency. The major advantage of the stochastic frontier production function model is the introduction of disturbance term representing noise, measurement error and exogenous factors beyond the control of the production unit, in addition to the inefficiency component. This property of the stochastic frontier model account for its appropriateness for efficiency measurement in agricultural production owing to agriculture's inherent characteristics.

In recent years, the application of stochastic frontier production function in efficiency analysis has been employed by Battese et al (1993). Seyoum et al (1998), Ojo (2003), Amaza and Tashikalma (2003), Amos et al (2004), Amaza and Maurice (2005), Umoh (2006).

The objective of the study therefore was to investigate the technical efficiency in Sorghum production in Hong local government area of Adamawa state.

\section{MATERIALS AND METHODS}

The study was carried out in Hong local government area of Adamawa state. Hong is located in the northern part of Adamawa State, it lies between latitude 7-11 $\mathrm{N}$ and longitude 11-14 E. The local government was created in 1991. Hong local government area shares boundary with Mubi local government to the East, Gombi local government area to the West, Song and Maiha local area to the South and Askira Uba local government area of Borno State to the
North. Hong local government has a land area of about 117,240 square kilometers with a population of about 169,126 (National Population Commission, 2006). The major occupation of the people is farming and few traders, civil servants etc. The major crops grown in the area are groundnut, sorghum, maize rice millet etc. the local government has seven district.

A multi stage random and purposive sampling techniques were used to select respondents for the study. Firstly 5 districts out of the eleven districts in the local government area were selected based on their relative importance in sorghum production. Secondly, two villages were randomly chosen from each of the selected district giving a total of 10 selected villages. Finally 10 farmers were selected randomly from each of the selected villages. Data were collected with the aid of structured questionnaires on households' sorghum production activities of the farmers. Data were also collected on the socioeconomic characteristics of the farmers.

Data were analyzed using the stochastic frontier model ( Battese and Coelli 2005). The stochastic production function is of the form:

$$
\begin{gathered}
\mathrm{Yi}=\mathrm{f}\left(\mathrm{X}_{\mathrm{k}} \beta\right) \epsilon_{\mathrm{i}} \quad(1) \\
\mathrm{i} \ldots \ldots \ldots \ldots \mathrm{n} \\
\mathrm{k}=1 \ldots \ldots \ldots \mathrm{k}
\end{gathered}
$$

Where:

$\mathrm{Y}_{\mathrm{i}}=$ output of the ith farm,

$\mathrm{X}_{\mathrm{k}}=$ vector of parameters.

This stochastic frontier is also called a' composed error' model because the error term is composed of two independent elements:

$$
\varepsilon_{i}=v_{i}-u_{i}
$$

The symmetric component Vi permits random variations in output due to factors outside the farm such as weather and disease as well as the effects of measurement error in the output variable, left out explanatory variables from the model and stochastic noise. It is assumed to be independently and identically distributed as $\mathrm{N}\left(0, \sigma_{\mathrm{v}}^{2}\right)$. A Ui is a one sided non negative $(\mathrm{u}>0)$ random variable which reflects the technical efficiency relative to the stochastic frontier. $\mathrm{f}(\mathrm{Xi}$, $\beta) \mathrm{e}^{\mathrm{v}_{\mathrm{i}}}$, thus Ui $=0$ for any output lying on the frontier and is strictly positive for any output lying below the frontier representing the amount by 
which the frontier exceeds the actual output of firm i. Ui is assumed to be identically and independently distributed as $\mathrm{N}\left(0, \sigma_{\mathrm{U}}^{2}\right)$, that is the distribution of $\mathrm{U}$ is half normal.

It follows that the maximum likelihood of equation 1 yields estimate for $\beta$ and $\lambda$ where $\beta$ was as earlier defined as:

and

$$
\lambda=\sigma_{u} / \sigma_{v}
$$

$$
\sigma^{2}=\sigma_{v}^{2}+\sigma_{u}^{2}
$$

Battese and cora (1977) on the other hand defined $\lambda$ as the total variation in output from the frontier which is attributable to TE, that is

$$
\gamma=\sigma_{u}^{2} / \sigma^{2}
$$

So that $0 \leq \gamma \leq 1$. An estimate of $\gamma$ can be obtained from estimates of $\sigma^{2}$ and $\lambda$.

The frontier production functions 1 and 2 is defined by the logarithm of production, therefore the production for the ith $\operatorname{farm}, \exp \left(\mathrm{Y}_{\mathrm{i}}\right)$. The measure of technical efficiency (TE) for the ith farm is thus:

$$
\mathrm{TE}_{\mathrm{i}}=\exp \left(-\mathrm{u}_{\mathrm{i}}\right)
$$

So that $0 \leq \mathrm{TEi} \leq 1$. The measure of technical efficiency is equivalent to the ratio of the production for the ith farm, $\exp \left(\mathrm{Y}_{\mathrm{i}}\right)=\exp \left(\mathrm{X}_{\mathrm{i}}, \beta+\mathrm{V}_{\mathrm{i}}-\right.$ $\left.\mathrm{U}_{\mathrm{i}}\right)$ to the corresponding production value if the effect of I was zero, $\exp \left(X_{i}, \beta+V_{i}\right)$. The technical efficiency measure( 6 ) is not dependent on the level of factor input for the given firm. The mean technical efficiency of the farms that corresponds to the measure of equation (6):

$$
\mathrm{TE}=\left\{1-\varphi\{\sigma-(\mu / \sigma)\} / 1-\varphi(-\mu / \sigma) \exp \left(-\mathrm{U}+1 / 2 \sigma^{2}\right)\right.
$$

Where $\varphi$ represents the density function for the standard normal random variables. The frontier production function specified for the yam enterprises in the prevailing state was defined by:

$\log Y_{i}=\beta_{0}+\beta_{1} X_{1 i}+\beta_{2} X_{2 i}+\beta_{3} X_{3 i}+\beta_{4} X_{4 i}+\beta_{5 i} X+B_{6} X_{6 i}+V_{i}-U_{i}$

Where:

$\mathrm{Y}=$ logarithm of the output $(\mathrm{kg})$

$\mathrm{X}_{1}=$ Land cultivated (hectares),

$\mathrm{X}_{2}=$ quantity of seed $(\mathrm{kg})$,

$\mathrm{X}_{3}=$ family labour used (in mandays),
$\mathrm{X}_{4}=$ quantity of hired labour used (mandays),

$\mathrm{X}_{5}=$ quantity of fertilizer use $(\mathrm{kg})$,

$\mathrm{X}_{6}=$ quantity of herbicide used (litres).

The random variables $\mathrm{V}_{\mathrm{i}}$ and $\mathrm{U}_{\mathrm{i}}$ in the model 2 were assumed to have the properties specified for the corresponding unobserved random variables in the frontier production model 1 and 2. $\mathrm{U}_{\mathrm{i}}$ denotes inefficiency effects, defined as:

$$
\mathrm{U}_{\mathrm{i}}=\delta_{0}+\delta_{1} \mathrm{Z}_{1}+\delta_{2} \mathrm{Z}_{2}+\delta_{3} \mathrm{Z}_{3}+\delta_{4} \mathrm{Z}_{4}+\delta_{5} \mathrm{Z}_{5}
$$

\section{Where:}

$\mathrm{Z}_{1}=$ Education (number of years of education), $Z_{2}=$ membership of association (dummy, 1 for membership 0, otherwise), $Z_{3}=$ extension contact (number of visits by extension agent), $\mathrm{Z}_{4}=$ household size (number of persons in household) $\mathrm{Z}_{5}=$ gender (dummy 1 for male and 0 female).

Given the functional and distributional assumptions, the variance parameters defined by equations( 4) and( 5), the technical efficiency defined by equation (6) and the maximum likelihood estimates for all parameters of the stochastic frontier production and inefficiency model by equation (8) and (9) were simultaneously estimated using the program, frontier 4.1 (Coelli 1996).

\section{RESULTS AND DISCUSSION}

The estimates of the parameters of the stochastic frontier production function are presented in table 1 . The production function estimates indicates the relative importance of factor inputs in sorghum production. From the results, all had the expected positive sign. This suggest that more output of sorghum would be obtained from the used of additional quantities of these variables. The estimated coefficient of land resource was positive and significant at $1 \%$ level. This is in line with the finding of Umoh (2006). The significance of the variable could be attributed to its importance in crop production in the sense that its shortage would not only have a direct negative effect on the production but also an indirect negative effect on output. The coefficient of seed was also positive which confirms to a prior expectation and significant at 5\% level. This indicated that higher seed rate would result in high sorghum yield except where there is overcrowding leading to competition of available nutrients which will consequently lead to lower yield. The estimated coefficient of Fertilizer input was posi- 
tive as expected and significant at $1 \%$ level. The significance of the fertilizer variable shows that used of fertilizer improves the productivity of the land.

The elasticities with respect to land seed and fertilizer were positive. This indicates that allocations of these resources were in the rationale stage (stage 2) of the production process and increase in the use of the resources would result in increase in yield. The estimated return to scale (RTS) was 0.5439 suggesting a decreasing return to scale. The study of this study implied that a unit increase in the quantities of the productive resources would lead to less than proportionate increase to output of sorghum, ceteris parabus.

The variance ratio $(\gamma)$ which is associated with the variance of technical inefficiency effects in the stochastic frontier was estimated to be 0.6062 . This suggested that systematic influence that are unexplained by the production function were the dominant sources of random errors. In other words, it means that $60 \%$ of the total variability of sorghum output for the farmers was due to differences in technical efficiencies.

Table 1 - Maximum likelihood estimates for parameters of the cobb-douglas stochastic frontier production function

\begin{tabular}{|l|l|l|} 
& & \\
\hline
\end{tabular}

* Significant at $1 \%$ level, ** significant at 5\%. Source: computed print out of field data 2010.

The sources of inefficiency were examined by using the estimate $\delta$-coefficients associated with the variables. The inefficiency variable was specified as those relating to farmer's socioeconomic characteristics. They include the farmer's level of educational attainment, membership of association, contact with extension agents, household size and gender. The result of the inefficiency model is presented in Table 2.The sign of the estimated coefficient in the model have important implication on the technical efficiency of sorghum production. The coefficient of education was estimated to be negative and is significant at $1 \%$. This indicates that farmers with more years of formal schooling tend to be more technically efficient. This agrees with the findings of Uaiene and Arndt (2009) and Bozoglu and Ceyhan (2007). They asserted that more years of formal education is imperative to better understand and adoption of new technology which subsequently make it possible to move close to the frontier. Furthermore, educated farmers are expected to be more receptive to improved farming techniques and therefore should have higher level of technical efficiency than farmers with less education (Ajibefun and Aderinola 2003). Farmers with low level of education would be less receptive to improved farming techniques.

Table 2 - Maximum likelihood estimates for parameters of the Cobb-Douglas inefficiency model for Sorghum farmers

\begin{tabular}{|c|c|c|c|}
\hline Variable & Parameters & Coefficients & t-ratio \\
\hline \multicolumn{4}{|c|}{ Inefficiency variables } \\
\hline Constant & 80 & -0.3146 & $-3.3391 *$ \\
\hline Education & $\delta 1$ & -0.4809 & $-2.9753 *$ \\
\hline Membership of Association & $\delta 2$ & -0.0625 & -0.0623 \\
\hline Extension contact & $\delta 3$ & -0.4570 & $-5.0280 *$ \\
\hline Household size & $\delta 4$ & -0.9454 & $-2.3036 * *$ \\
\hline Gender & $\delta 5$ & -0.1816 & -0.3668 \\
\hline
\end{tabular}

** Significant at 5\% level, * significant at 1\%. Source: field data, 2010. 
The predicted coefficient of household size was negative and is significant at $5 \%$. indicating that these variable led to decrease in technical inefficiency or increase in technical efficiency, also the negative coefficient was in agreement with the hypothesized expected sign and implied that as the number of adult farmers in a household increases, efficiency also increases. This agreed with the findings of Villano and Fleming(2004). A possible explanation is that more adult persons in a household meant that more quality labour would be available for carrying out farming activities in timely fashion, thus making the production process more efficient.

The technical efficiencies of the sample sorghum farmers were less than one. The predicted farm specific technical efficiency for the farmers ranged from 0.15 to 0.92 with a mean technical efficiency of 0.72 (Table 3). This imply that in the short run, there is scope for increasing sorghum production by about $28 \%$ by adopting the technology and techniques used by the best practice farmer. It also shows that about $64 \%$ of the farmers have technical efficiency of more than $70 \%$.

Table 3 - Frequency Distribution of Technical efficiency in Sorghum Production*

\begin{tabular}{|c|c|c|}
\hline Efficiency level & Frequency & $\%$ \\
\hline$\leq 0.15$ & 2 & 2 \\
\hline $0.30-0.39$ & 1 & 1 \\
\hline $0.40-0.49$ & 1 & 1 \\
\hline $0.50-0.59$ & 6 & 6 \\
\hline $0.60-0.69$ & 26 & 26 \\
\hline $0.70-0.79$ & 29 & 29 \\
\hline $0.80-0.89$ & 30 & 30 \\
\hline $0.90-1.00$ & 5 & 5 \\
\hline Total & 100 & 100 \\
\hline Mean efficiency & 0.7262 & - \\
\hline Minimum efficiency & 0.1562 & - \\
\hline Maximum efficiency & 0.9214 & - \\
\hline
\end{tabular}

* Source computed from MLE result.

From the results of the study, it should be noted that technical efficiency of the sorghum farmers varied due to the presences of technical inefficiency. The attainment of an average technical efficiency of $72 \%$ indicates that efficiency of the farmers could be increased by about $28 \%$ to attain maximum possible output. The results also suggests that farmers could increase output through more intensive use of land, seed and fertilizer inputs given the prevailing state of technology. This could be achieved through development of land by the government, prices of im- proved seeds and fertilizers at the grass root should also be considered by the government so that the farmers can have access to these inputs at the right time and affordable. In the long run term, higher technical efficiency could be achieved by improving farmers' educational status. Also, extension agents should be adequately made available to the farmers at all times, so that they will have first hand information on new farming techniques and new innovations in agricultural production that would ensure increased sorghum production in the study area.

\section{REFERENCES}

Akinleye, S.O. (2006). Technical efficiency of arable crop farming in Ijebu division of ogun state. A paper presented at the farm management association of Nigeria conference, Jos, Nigeria, September 18-21.

Aigner, D., Lovell, C.A.K., Schmidt, P. (1977). Formulation and estimation of stochastic frontier production function models. Journal of Econometrics, 6:21-37.

Ajibefun, I. A ,Aderinola,E. A. (2003). Determinants of technical efficiency and policy implication in traditional agricultural production. Empirical study of Nigerian crop far- mers. Report presented at the Bi-annual research workshop of AERC, Nairobi Kenya, May 24-29.

Amaza, P.S., Tashikalma, A.K. (2003). Technical efficiency of groundnuts production in Adamawa state, Nigeria. Journal of arid agriculture, 13: 127-31.

Amaze, P.S., Maurice, D.C. (2005). Identification of factors that influence technical efficiency in rice based production system in Nigeria, paper presented at workshop on policies and strategies for promoting rice production and food security in sub-saharan Africa, Coto- 
nou, Benin republic, Novermber 7-9.

Amos, T.T., Chikwendu, D.O., Nmadu, J.N. (2004). Productivity, technical efficiency and cropping patterns in the savannah zone of Nigeria. Journal of food agriculture and environ, 2:173-176.

Battese, G.E. Cora, .G.S (1977). Estimation of a production frontier model: with application to postoral zone of eastern Australia. Australian journal of agricultural economics, 21:167-179.

Baiyegunhi, L.J.S and G.C.G. Fraser, (2009). Profitability in sorghum production in three villages of Kaduna state, Nigeria. Journal of applied sciences research, 5(10):1685-1691.

Baiyegunhi, L.J.S., G.C.G. Fraser and M.O. Adewumi (2010). Resource use efficiency in sole sorghum production in three villages of Kaduna state, Nigeria. African journal of agricultural research, vol. 5(3)::172-177.

Battese, G.E., Malik, S.G, Broca, S. (1993). Production function for wheat farmers in selected district of Pakistan: An application of a stochastic frontier production function with time varying inefficiency effects. The Pakistan development review, 32:233-268.

Bozoglu, M. Ceyhan, V (2007). Measuring the technical efficiency and exploring the inefficiency determinants of vegetable farms in samsung province. Turkey. Agric Syst. 94: 649-656.

Coelli, T.J. (1996). A Guide to FRONTIER Version 4.1: A computer program for stochastic frontier production and cost function estimation, CEPA Working paper 96/07 department of econometrics, University of New England, Armidale.

Debrah, S.K. (1993). Sorghum in West Africa. In sorghum and millet Commodity and research environment, ICRISAT, India.

FAO (2003). Cereal Production Annual Report vol.63. Rome, Italy.

Farrell, M.J. (1957). The measurement of production efficiency. Journal of royal stat soc. Series A, 120:253-281.

Federal Ministry of Agriculture, FMA 2001. Annual review, Abuja, Nigeria, Federal Capital Development Authority.

Helfand,S.M (2003). Farm size and determinants of productive efficiency in the brazillian centre west. Proceedings of the 25th international conference of agricultural economics. Durban, south Africa, august 16-22: pp 605-612.

Khumbhakar, S.C., Heshmatic, A. (1995). Efficiency measurement in Swedish dairy farms: An application of rotating panel data
1976-1988. American journal of agricultural economics, 77(3):660-674.

Meeusen, W., Van den Broeck J. (1977). Efficiency estimation for cobb-douglass production function with composed error, international economic review, 18:435-444.

National agricultural extension and rural liason services (1997). Prospects and problems of the 1997 cropping season. NAERLS/AP, MUE, Kaduna, Nigeria. National Bureau of Statistics Report, 2010.

Ogundele O.O (2003). Technology differentials and resource use efficiency in rice production in Kaduna State. Unpublished Ph.D. thesis . University of Ibadan, Nigeria.

Olayide, S.O and Heady, E.O (1982). Introduction to agricultural economics. Ibadan university press, university of Ibadan, Nigeria.

Ojo, S.O. (2003). Productivity and technical efficiency of poutry egg production in Nigeria. International journal of poutry science, 2: 459-464.

Seyoum, E.T., Battese, G.E., Fleming, E.M. (1998). Technical efficiency and productivity of maize farmers in eastern Ethiopia. A study of farmers within and outside the sasakawa-global 2000 project. Agricultural economics 19:341-348.

Tadesse B, Krishnamoorrthy S (1997). Technical efficiency in paddy farms of tamil naduc: An analysis based on farm size and ecological zone. Agricultural economics, 16: 185-192.

Uaiene, R.W. and Arndt,C. (2009). Farm household technical efficiency in mozambique. A paper presented at the international association of agricultural economist conference. Beijing, China, 16-22 August.

Umoh, G.S. (2006). Resource use efficiency in urban farming: an application of stochastic frontier production function. International journal of agric bio, 8: 34-44.

Villano, R., Fleming, E. (2004). Anaysis of technical efficiency in a rain fed lowland rice environment in central Luzon philipines using a stochastic frontier production function with heteroskedastic error structure, working paper series in agricultural and resource economics no.2004-15. University of new England, Australia.

Yao, S. and Liu, Z. (1999). Determinants of grains production and technical efficiency in china. Journal of agricultural economics, 49(2):171-184.

Zaibet L.,Dharmapala P.S. (1999). Efficiency of government supported horticulture: The case of Oman. Agricultural systems, 62:159-168. 